limitation in the supply of thymus-seeding cells in mice of a similar age.

Cancer Research Laboratory,

Walter and Eliza Hall Institute, Royal Melbourne Hospital,

Victoria, Australia.

${ }^{2}$ Harris, J. E., Barnes, D. W. H., Ford, C. E., and Evans, E. P., Nature, 201, 884 (1964).

${ }^{2}$ Miller, J. F. A. P., CIBA Symp. Tumour Viruses of Murine Origin, 262 (J. and A. Churehill, London, 1962).

s Metcalf, D., and Wakonig-Vaartaja, R., Proc. Soc. Exp. Biol. and Med., 115, 731 (1964).

${ }^{4}$ Metcalf, D., in The Thymus, edit. by Defendi, V., and Metcalf, D., 53 (Wistar Institute Press, Philad., 1964).

s Metcalf, D., A ustral. J. Exp. Biol. and Med. Sci., 41, 437 (1963)

'Makinodan, T., and Peterson, W. J., J. Immunol., 98, 886 (1964).

\section{Role of Sialic Acid in Potassium Transport of L1210 Leukaemia Cells}

THE cell membranes of various tumour strains possess large quantities of sialic acid and a strong, negative surface charge ${ }^{1-5}$. This charge, which is partly due to the ionized carboxyl group of sialic acid ${ }^{2,4,5}$, may be important in influencing physiological properties such as transport of ions ${ }^{6}$. Since tumour cells seem to concentrate $\mathrm{K}^{+}$ions better than normal cells ${ }^{7-9}$, we have begun to investigate the regulation of $\mathrm{K}^{+}$fluxes by sialic acid.

L1210 mouse leukaemia cells, which had been maintained in the ascitic form, were washed at $3^{\circ} \mathrm{C}$ with isotonic saline until free of red blood cells. The $L 1210$ cells were then incubated for $90 \mathrm{~min}$ at $37^{\circ} \mathrm{C}$ in the incubation media shown in Table 1. Sialic acid was removed from the leukaemia cells by the addition of neuraminidase (Vibrio cholerae), which was present at a final concentration of 50 units $/ \mathrm{ml}$. Under these conditions the sialic acid released is derived essentially from the cell membrane ${ }^{4}$. Free sialic acid was determined by the method of Warren ${ }^{10}$. $\mathrm{Na}^{+}$and $\mathrm{K}^{+}$ions were assayed by means of a flame spectrophotometer. The optimum wave-lengths were $589 \mathrm{~m} \mu$ for $\mathrm{Na}^{+}$and $766.5 \mathrm{~m} \mu$ for $\mathrm{K}^{+}$. ${ }^{14} \mathrm{C}$-D-Glucose $\left(5 \cdot 2 \times 10^{3}\right.$ c.p.m. $/$ mole $)$ and ${ }^{14} \mathrm{C}$-L-lysine $\left(1.6 \times 10^{5}\right.$ c.p.m./ $/$ mole $)$ were utilized in measuring glucose and lysine uptakes.

\begin{tabular}{|c|c|c|c|c|c|}
\hline Substance & $\begin{array}{l}\text { Conc. } \\
\text { (mM) }\end{array}$ & K-free & $\begin{array}{l}\text { Incubat } \\
\mathrm{K} \text {-lowg }\end{array}$ & $\underset{\mathbf{K} \text {-free } g_{, 1}}{\text { medium }}$ & $\mathrm{K}$-lowg, \\
\hline L-Lysine & $0 \cdot 2$ & - & - & + & + \\
\hline D-Glucose & $4 \cdot 9$ & - & + & + & + \\
\hline KCl & $10 \cdot 0$ & - & + & - & + \\
\hline $\mathrm{NaCl}$ & $130 \cdot 2$ & - & + & - & + \\
\hline $\mathrm{NaCl}$ & $140 \cdot 2$ & + & - & + & - \\
\hline $\mathrm{Na}_{2} \mathrm{HPO}_{4}$ & $4 \cdot 8$ & + & + & + & + \\
\hline $\mathrm{NaH}_{2} \mathrm{PO}_{4}$ & $5 \cdot 2$ & + & + & + & + \\
\hline $\mathrm{CaCl}_{2}$ & $0 \cdot 9$ & + & + & + & + \\
\hline $\mathrm{CH}_{3} \mathrm{COONa}$ & $5 \cdot 0$ & + & + & + & + \\
\hline
\end{tabular}

The amounts of sialic acid removed by neuraminidase in the $\mathrm{K}$-free medium were $0.21 \mu \mathrm{mole} / 100 \mathrm{mg}$ dry wt of cells after $45 \mathrm{~min}$ of incubation and $0.23 \mu \mathrm{mole} / 100 \mathrm{mg}$ dry wt at $90 \mathrm{~min}$. The quantities of sialic acid released were nearly the same in any of the incubation media listed in Table 1, and the values obtained approximated those determined for the Ehrlich ascites tumour cell ${ }^{4}$.

Different incubation media were utilized in the transport investigations, so that the direction of ion flow could be altered. In the $\mathrm{K}$-free medium, $\mathrm{K}^{+}$release from the $L 1210$ cells accompanied $\mathrm{Na}^{+}$uptake; with the K-low medium, $\mathrm{K}^{+}$uptake accompanied $\mathrm{Na}^{+}$release. Table 2 includes the results of typical experiments, in which the removal of sialic acid inhibited $\mathbf{K}^{+}$transport, regardless of direction of flow. When the results from a number of experiments were pooled, the differences between the control and the experimental groups were found to be statistically significant $(P<0 \cdot 05)$. Contrary to the relatively sharp response of $\mathrm{K}^{+}$ions to the removal of sialic acid, $\mathrm{Na}^{+}$transport was only slightly inhibited when neuraminidase was present, and in this case the results did not yield significant differences.
Table 2. TRANSPort in L1210 Cells stripped of Sialic ACID

\begin{tabular}{|c|c|c|c|c|}
\hline Medium & $\begin{array}{l}\text { Substance } \\
\text { measured }\end{array}$ & $\begin{array}{l}\text { Time } \\
(\min )\end{array}$ & $\begin{array}{c}\mu \text { moles } / 100 \\
\text { Control }\end{array}$ & $\begin{array}{l}\text { mg dry wt. of cells } \\
+ \text { Neuraminidase }\end{array}$ \\
\hline $\mathbf{K}$-free & $\mathbf{K}^{+}$ & $\begin{array}{l}45 \\
90\end{array}$ & $\begin{array}{l}-2 \cdot 56 \\
-4 \cdot 60\end{array}$ & $\begin{array}{l}-1.97(23) \\
-3.40(26)\end{array}$ \\
\hline & $\mathrm{Na}^{+}$ & $\begin{array}{l}45 \\
90\end{array}$ & $\begin{array}{l}+15 \cdot 1 \\
+13 \cdot 8\end{array}$ & $\begin{array}{l}+13 \cdot 4(11) \\
+12 \cdot 0(13)\end{array}$ \\
\hline $\mathrm{K}-\mathrm{low} g$ & $\mathbf{K}^{+}$ & $\begin{array}{l}45 \\
90\end{array}$ & $\begin{array}{l}+25.0 \\
+26.0\end{array}$ & $\begin{array}{l}+16.0(36) \\
+17.0(35)\end{array}$ \\
\hline $\mathrm{K}$-lowg & $\begin{array}{l}\mathrm{Na}{ }^{+} \\
\mathrm{D} \text {-glucose }\end{array}$ & $\begin{array}{l}45 \\
45 \\
90\end{array}$ & $\begin{array}{l}-50 \cdot 0 \\
+3 \cdot 13 \\
+6 \cdot 31\end{array}$ & $\begin{array}{r}-45.0(10) \\
+3.09(1) \\
+6.25(1)\end{array}$ \\
\hline $\begin{array}{l}\text { K-free } g_{, 1} \\
\text { K-low } g_{, 1}\end{array}$ & $\begin{array}{l}\text { L-lysine } \\
\text { L-lysine }\end{array}$ & $\begin{array}{l}45 \\
45\end{array}$ & $\begin{array}{l}+0.208 \\
+0.206\end{array}$ & $\begin{array}{l}+0.204(2) \\
+0.207(0)\end{array}$ \\
\hline
\end{tabular}

(+) Indicates flow into the cells; $(-)$ indicates flow out of the cells. Per$(+)$ Indicates flow into the cells; $(-)$ indicates flow out of the cell
centage decreases from the control values are given in parentheses.

Glucose uptake was determined for both the control cells and the enzyme-treated cells and did not appear to differ between the two groups. This finding suggests that transport in general was not affected by sialic acid, and that $\mathrm{K}^{+}$transport in particular was not regulated by the action of membrane-bound sialic acid on glucose utilization. Furthermore, although glucose was absent from the $\mathrm{K}$-free medium, the removal of sialic acid inhibited $\mathrm{K}^{+}$outflow.

Finally, sialic acid was found not to affect lysine uptake in the absence or presence of $\mathrm{K}^{+}$ions, thereby indicating that sialic acid does not influence transport of positively charged substances in general.

Pardee ${ }^{11}$ has postulated that altered surface properties of tumour cells may cause a loss of growth control mechanisms. The accumulation of $\mathrm{K}^{+}$ions in malignant cells $^{2-9}$ may well be such a mechanism, which is partly responsible for the adaptation of these cells to a state of uncontrolled growth. The presence of $\mathbf{K}^{+}$ions is necessary for optimal growth of certain bacteria strains ${ }^{12,13}$ and plant tumours ${ }^{14,15}$. Lubin ${ }^{16}$ has demonstrated a control of protein synthesis by $\mathrm{K}^{+}$accumulation. The work recorded here in turn indicates that sialic acid apparently mediates both the inward and outward diffusion of $\mathbf{K}^{+}$ions in a leukaemia cell.

We thank Prof. Arthur B. Pardee for his advice. This work was supported by grants $1-F 2-C A-24245-01$ and $A I-04409$ from the U.S. Public Health Service. J. LESLIE GLICK SHERWOOD GITHENS III

Department of Biology,

Princeton University,

Princeton, New Jersey.

1 Defendi, V., and Gasic, G., J. Cell. Comp. Physiol., 62, 23 (1963).

2 Forrester, J. A. Ambrose, E. J, and Macpherson, J. A., Nature, 196, 1068 (1962).

Miller, A., Sullivan, J. F., and Katz, J. H., Cancer Res., 23, 485 (1963)

4 Wallach, D. F. H., and Eylar, E. H., Biochim. Biophys. Acta, 52, 594 (1961).

Wallach, D. F. H., and de Perez Esandi, M. V., Biochim. Biophys. Acta, 83, $363(1964)$.

6 Hempling, H. G., J. Cell. Camp. Physiol., 60, 181 (1962).

7 Brunschwig, A., Dunham, L. J., and Nichols, S., Cancer Res., 6, 230 (1946).

Dunham, L. J., Nichols, S., and Brunschwig, A., Cancer Res., 6, 233 (1946). ' DeLong, R. P., Coman, D. R., and Zeidman, I., Cancer, 3, 718 (1950).

10 Warren, L., J. Biol. Chem., 234, 1971 (1959).

11 Pardee, A. B., Nat. Cancer Inst. Monograph, 14, 7 (1964).

${ }^{12}$ Lubin, M., and Kessel, D., Biochem. Biophys. Res. Comm., 2, 249 (1960).

13 Damadian, R., and Solomon, A. K., Seience, 145, 1327 (1964).

${ }^{14}$ Wood, H. N., and Braun, A. C., Proc. U.S. Nat. Acad. Sci., 47, 1907 (1961). ${ }^{15}$ Braun, A. C., and Wood, H. N., Proe. U.S. Nat. Acad. Sci., 48, 1776 (1982).

${ }^{16}$ Lubin, M., Fed. Proe., 23, 994 (1964).

\section{Occurrence of Fructose-I-phosphate in Tissues of Higher Plants}

THEre is considerable evidence for a role of fructose- 1 . phosphate in the metabolism of some animal tissues ${ }^{1}$. Relatively little is known about the occurrence of this compound in higher plants. Cardini ${ }^{2}$ has shown that preparations of jack bean seeds can cleave fructose-1phosphate to dihydroxyacetone phosphate and a compound which is probably glyceraldehyde. On the basis of electrophoretic separation, Schwimmer, Bevenue and Weston ${ }^{3,4}$ tentatively identified fructose-1-phosphate in extracts of potatoes. We report here evidence for the 